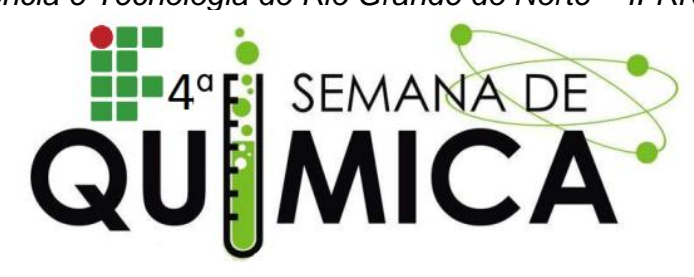

\title{
CARACTERIZAÇÃO FÍSICO-QUÍMICA DE LICORES COMERCIAIS À BASE DE FRUTAS
}

ARAÚJO, C. V.; CORCINO, M. A.; SOUTO, M. R.; COELHO, M. V.; FAGUNDES T. S.; CARVALHO SANTOS, J. S. (IFRN)

Palavras Chave: Licores, característica físico-química.

\section{INTRODUÇÃO}

A legislação brasileira (Lei no 8.918 , de 14 de julho de 1994, regulamentada pelo decreto n. 6.871 de 4 de junho de 2009) define licores e estabelece seus padrões. O licor deve conter graduação alcoólica de 15 a $54 \%$ em volume, a $20^{\circ} \mathrm{C}$, e o açúcar superior a 30 $\mathrm{g} / \mathrm{L}$, elaborado com álcool etílico potável de origem agrícola, adicionada de extratos ou aromatizantes, saborizantes, corantes e outros aditivos (BRASIL, 1997).

A associação adequada do teor alcoólico e quantidade de açúcar desempenham um papel fundamental quanto à aceitação do licor por parte dos consumidores (Teixeira et al., 2007). Podem ser denominados de seco, fino ou doce, creme, escarchado ou cristalino, sendo que o licor seco é a bebida contendo mais de trinta e, no máximo, 100 cem gramas de açúcares por litro (Pereira et al., 2008).

Existem vários métodos de fabricação de licores, dois deles são: por infusão e por destilação. Na produção por infusão os licores são elaborados com substancias cujo princípio aromático não pode ser extraído por destilação com água ou com álcool. Alguns desses licores recebem o nome de ratafiá, que em geral são preparados com partes frescas de vegetais, tais como frutas (VENTURINI, 2010). Já a destilação é o processo que assegura alta qualidade ao licor. Consiste em preparar o macerado da parte vegetal desejada em álcool ou água e a seguir destilar, de preferência, através do vapor (VENTURINI, 2010).
0 trabalho teve o intuito de avaliar as características físico-químicas dos licores comerciais à base de frutas. As principais características foram o $\mathrm{pH}, \mathrm{O}^{\circ}$ Brix e a densidade.

\section{METODOLOGIA}

Foram determinadas as características físicoquímicas dos licores que estão representados na Figura 1 , sendo subdivididas em três etapas: $\mathrm{pH},{ }^{\circ} \mathrm{Brix}$, e densidades. Foram utilizados licores dos sabores cajá, pitanga, morango e maracujá, de fabricantes distintos, e todos foram numerados de 1 a 4 respectivamente.

Figura 1: Amostras dos licores estudados

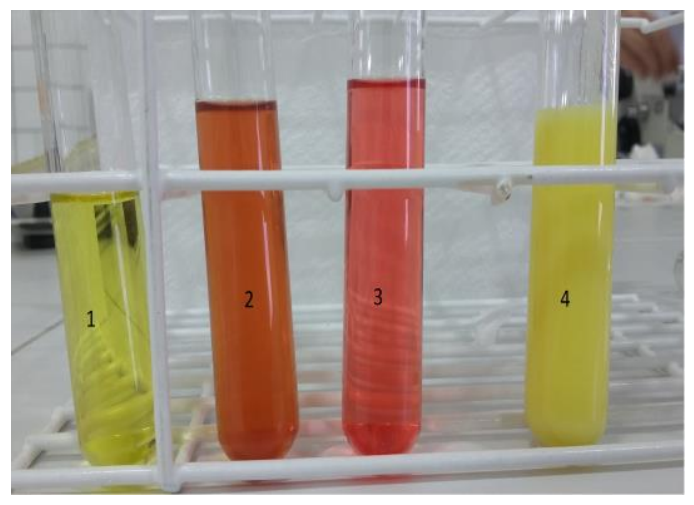

Etapa 1: A medição do $\mathrm{pH}$ foi realizada em um pHmetro TECNOPON mPA. As análises foram realizadas com o intuito de identificar - nível de acidez dos mesmos. Nesse processo, foram utilizadas cerca de $100 \mathrm{~mL}$ de cada.

Etapa 2: Na análise de grau Brix podemos identificar índice de refração das amostras bebidas. Foi necessário preparar alguns padrões de sacarose para a calibração do equipamento. Em seguida, adicionamos uma 

pequena quantidade da amostra no prisma do refratômetro. Para obter os valores, utilizamos o refratômetro Abbe De Bancada Q767B.

Etapa 3: Para medir a densidade dos licores utilizamos o densímetro Anton Paar DMA $4500 \mathrm{~m}$, para que pudéssemos saber qual das quatro amostras seria a mais e menos densa. Todas as análises foram realizadas em triplicatas.

Na Tabela 1 estão apresentados os teores alcoólicos dos licores segundo o fabricante.

Tabela 1: Teor alcoólico dos licores.

\begin{tabular}{cc}
\hline Licores & Teor Alcoólico (\%) \\
\hline $\mathbf{1}$ & 15,6 \\
$\mathbf{2}$ & 15 \\
$\mathbf{3}$ & 20 \\
$\mathbf{4}$ & 9,6 \\
\hline
\end{tabular}

\section{RESULTADOS E DISCUSSÕES}

Após analisarmos as características físicoquímicas (Tabela 2) dos quatros licores comerciais e levando em consideração as condições normais de temperatura e pressão $\left(25^{\circ} \mathrm{C}\right.$ e $\left.1 \mathrm{~atm}\right)$ obtivemos os seguintes resultados:

Tabela 2: Características físico- químicas dos licores.

\begin{tabular}{cccc}
\hline Licores & pH & ${ }^{\circ}$ Brix & $\mathbf{d}\left(\mathbf{k g} / \mathbf{m}^{\mathbf{3}}\right)$ \\
\hline $\mathbf{1}$ & 2,94 & 37,2 & 1153,88 \\
$\mathbf{2}$ & 3,65 & 41,9 & 1168,14 \\
$\mathbf{3}$ & 3,50 & 41,0 & 1116,13 \\
$\mathbf{4}$ & 4,82 & 45,8 & 1176,73 \\
\hline
\end{tabular}

Podemos observar que, segundo a legislação brasileira, todos os licores apresentam valores dentro do permitido para serem comercializados. O licor 4 apontou valores maiores do que os demais, devido a presença do leite condensado na sua fabricação, deixando-o com o sabor mais doce e com o pH menos ácido. Já o licor 1 , foi o que expressou valores mais baixos, ou seja, o seu potencial de hidrogênio $(\mathrm{pH})$ é o mais acentuado, provavelmente devido o tipo de fruta, como também, teor de açúcar inferior aos outros licores. As amostras 2 e 3, mostraram valores intermediários e ambos

4ª Semana de Química - IFRN, 2016 são bem parecidos em suas características. Os pHs encontrados, com valores entre 2,94 e 4,82 para os licores estudados foi praticamente igual ao encontrado por PENHA (2001), que obteve $\mathrm{pH}$ de 3,6 para o licor de acerola. A densidade é proporcional aos teores de sólidos solúveis, uma vez que os componentes álcool e açúcar encontramse ajustados, a presença do leite condensado no licor 4, fez com que a densidade mesmo apresentasse valor acima dos demais.

\section{CONCLUSÃO}

Todos os licores analisados estão dentro dos valores determinados pela legislação, que estabelece um percentual de açúcar acima de trinta gramas por litro da bebida, ou seja, que seu grau Brix seja maior que $30 \%$.

$\mathrm{O} \mathrm{pH}$ baixo dificulta o desenvolvimento de microrganismos patogênicos e deteriorantes, o que é importante pois favorece a estabilidade do ácido ascórbico e aumento da vida útil do produto. Os valores das densidades também estão dentro do que é determinado pela legislação, apresentam valores entre 1150,00 e $1180,00 \mathrm{~kg} / \mathrm{m}^{3}$.

\section{REFERÊNCIAS}

1. BRASIL. Decreto n. 6.871 de 4 de junho de 2009. Regulamenta a Lei n. 8.918, de 14 de julho de 1994, que dispõem sobre a padronização, a classificação, o registro, a inspeção, a produção e a fiscalização de bebida. Disponível em: http://extranet.agricultura.gov.br/legisc onsulta/consultarLegislacao.do?operaca $\mathrm{o}=\mathrm{visu}$ alizar\&id=20271 acesso em 11/08/2016.

2. PEREIRA, K. S.; LEITE, D. S.; SANTOS, P. L. S.; CARDOSO, R. L. Elaboração, caracterização físico-química e sensorial de licor de corte de umbu. XXII Congresso Brasileiro de Fruticultura, Rio Grande do Sul, 2012.

3. VENTURINI, G. Bebidas Alcoólicas. Vol.1 2010. Cap.22. ALMEIDA PINA, C. Produção de licor de caju. TCC.

4. TEIXEIRA, L. J. Q. et al. Testes de aceitabilidade de licores de banana. Revista Brasileira de Agrociência, Pelotas, v. 13 n. 2, p. 205-209, 2007. 